\title{
THE IMPACT OF TERMS OF TRADE SHOCKS ON BALTIC COUNTRIES' AGRICULTURAL INDUSTRY
}

\author{
Jacek Strojny ${ }^{1}$, PhD hab. \\ ${ }^{1}$ University of Agriculture in Krakow, Institute of Statistics and Econometrics
}

\begin{abstract}
The aim of the study is to assess the impact of terms of trade shocks on Baltic States' agricultural industry. The research covers period of 2002 - 2017. The study is based on vector autoregression (VAR) methodology. The research encompasses the impulse response function (IRF) evaluation and analysis of the forecast error variance decomposition (FEVD). The impact of terms of trade changeability was subdivided into temporary and permanent effects. The split of the terms of trade affect was attained by time series transformation by means of Hodrick-Prescott filter. The research outcome revealed that temporary terms of trade shocks have an effect on Lithuanian agricultural trade relate this variable to trade balance changes of agri-food goods and to terms of trade development in all considered countries. The IRF function evaluation led to the conclusion that a positive impulse in permanent component of terms of trade causes sharp increase in variables considered in the model. The stabilisation of the system is attained after two periods. The outcome of the FEVD investigation led to the conclusion that terms of trade is the most exogenous factor within the considered system. On the other hand the most endogenous variable is gross value added of agricultural industry (GVA).
\end{abstract}

Key words: terms of trade, agi-food trade balance, vector autoregression, Baltic States.

JEL code: F19, N50, Q17.

\section{Introduction}

Economists point out that the literature bringing up the problems of the impact of the terms of trade fluctuations on the trade balance provide ambiguous instances of that relationship. Ultimately, the influence of terms of trade shocks on current account depends on a bulk of different factors as: the type of the change, duration of the shock, expectations in respect of changes' character, and type of the transmission channel.

Conventional explanation of on the of terms of trade fluctuation influence on trade balance which is associated with names Laursen and Metzler (1950) and Harberger (1950) intimates that the rise in terms of trade leads to an enhance of country's real income. This income rise is expressed as the purchasing ability of that country exports. Economic literature concerning terms of trade changeability and the impact of that quality on trade balance, or more broadly on the current account, generally focused on the way the variations of terns of trade affect private savings. The scientific literature suggests that terms of trade fluctuations may influence national savings and current account. However, the impact of terms of trade changeability could be split into temporary effect and long-run end product.

According to Harberger-Laursen-Metzler effect (HBL) temporary deterioration in terms of trade should lead to a deterioration of the current account as a result of decrease of real income. Consumers in order to maintain their standard life reduce the marginal propensity to save and increase marginal propensity to consume. Worsening relationship of imported / exported goods prices results in the deterioration of trade balance and a decline in national savings (Turnovsky, 1997). The opposite effect triggers temporary improvement in terms of trade which induces improvement in the current account and an increase of national savings. Chowdhury (2003) states that this results from consumers' perception of the income increase as the temporary (as the consequence of terms of trade improvement). Such consumers' expectations regarding character of rising income encourage them to reduce current consumption expenditure and to increase savings.

Laursen and Metzler (1950) acknowledge that deterioration in terms of trade may trigger two opposed absorption effects, namely income effect and substitution effect. Pursuant to the income effect, terms of

\footnotetext{
${ }^{1}$ Corresponding author. E-mail address: rrstrojn@cyf-kr.edu.pl
} 
trade deterioration results in a decrease of income, what affects negatively domestic expenditure on imported goods. On the contrary, in line with the substitution effect, suitable increase in prices of foreign goods leads to displacement of appreciating imports by getting chipper domestic products. Hence, ultimate product of terms of trade shocks on trade balance depends on the magnitude of these two impacts. Income effect prevalence at terms of trade deterioration tends to harm balance of payments. On other hand, dominance of substitution effect at terms of trade deterioration leads to improvement in trade balance. Such approach views trade imbalances as a consequence of domestic absorption. Absorption exceeds income if a country spends above its product. In consequence of exaggerated consumption, the trade balance is in deficit. If a country spends less than it fabricates, income exceeds absorption and its trade balance is in surplus.

When the possibilities of long-run substitution between domestic and foreign goods are considered deterioration in terms of trade (for example, derived from country's currency depreciation) leads ultimately to improvement of that country balance of payments. Although short-run consequences of international markets' prices fluctuations may be well adverse. However, long-run effect of foreign exchange rates control could lead to persistent surpluses or deficits in the trade balance. Therefore, Wang (2009) remarks that Harberger-Laursen-Metzler effect plays a significant role in discussions on effects of national currency depreciation on the balance of payments. Wang argues that assuming other things unchanged, a change in the currency rates which causes an increase in domestic absorption deteriorates trade balance, and any change in exchange rates that results in absorption decrease improves trade balance.

The purpose of the study is to examine the claims made for fluctuating terms of trade of agricultural products and their impact on trade balance of agri-food goods. The study sample consists of three countries: Estonia, Lithuania, and Latvia. The paper is organized as follows: next section first introduces a theoretical background to the research and provides the essence of the methodology. Subsequently, there are discussed the results of the empirical research - models investigating terms of trade impact that are performed for each Baltic State individually. Last section provides a summary and conclusions.

\section{Research results and discussion The research method}

In order to analyse the relationship between terms of trade changes and trade balance of agricultural products and food goods of Baltic States idea of econometric models quoted by Kent and Cashin (2003) was employed. However, for study purposes instead of the term of current account the notion of trade balance was used and the term of GDP (gross domestic product) was replaced with GVA (gross value added) of agricultural industry. These changes were introduced in the aftermath of industry analysis level. Furthermore, instead of panel methodology applied by Kent and Cashin vector autoregression technique (VAR) was employed (Lutkepohl, 1991; Kusidel, 2000). However, permanent impact of terms of trade changes was evaluated trough modification of VAR technique - by means of vector correction model (VECM). The temporary impact of terms of trade shocks was investigated using VAR model.

The data are from statistical database of EUROSTAT. Series are annual from 2002 to 2017. In the sample are three Baltic Countries (Estonia, Latvia, Lithuania). The data concern economic performance of the agricultural industries (GVA - gross value added), terms of trade of the agri-food goods, trade balance of agricultural, and food goods and exports and imports values of agri-food products.

A key objective of the paper is to assess the response of trade balance of agri-food goods to changes in terms of trade of agri-food products. Terms of trade may contain predictable and unanticipated components. Estimates of unanticipated element of terms of trade (shocks) were obtained as the residuals 
from filtered series. Namely, the original data representing terms of trade time series were transformed by means of Hodrick-Prescott mathematical filter (Hodrick, Prescott, 1997) in order to subdivide the process into two categories - temporary and permanent components. Therefore, permanent terms of trade changes were estimated by the mean of trend and temporary changes were assessed as cyclical residuals from terms of trend time series after applying mathematical filter (Agénor, Aizenman, 2000). Therefore, assessment of the impact of permanent and temporary terms of trade changes on the trade balance of agricultural industry entailed creation of two models - separately for each terms of trend effect.

Consecutive variables used in the study are coded as follows: hpt_ToT - terms of trade permanent component, hp_ToT - terms of trade temporary component, Rat - exports value / imports value ratio, Bal - trade balance in agri-food goods, GVA - gross value added of agricultural industry. Additionally, a particular model may contain terms as: const - constant, time - time variable, EC1 - error correction term.

Before VAR model parameter estimation, it was essential to assess stationarity of considered time series. KPSS tests of stationarity (Kwiatkowski et al., 1992), revealed that generally examined variables showed evidence of stationarity. Additionally, most of the variables shows evidence of a trend for all countries.

The trade balance response to terms of trade variation and impact of terms of trade changes on GVA of agricultural industry was examined by the mean of VAR methodology. Determination of the model form (VAR or VECM) was achieved by the cointegration likelihood test developed by Johansen (1988). After models' parameter estimation, the statistical quality of the equations was accessed by computing the relevant statistical diagnostics (not presented because of constrains on article volume). Additionally, the research encompassed the impulse response function (IRF) evaluation and the forecast error variance decomposition (FEVD).

\section{Terms of trade changes impact on agricultural industry of Estonia}

For permanent terms of trade changes Johansen cointegration test based on trace statistical test $(r>=$ $\left.1 \lambda_{\text {trace }}=10.025 p=0.4857\right)$ and the maximum eigenvalue test $\left(r=1 \lambda_{\max }=9.918 p=0.4122\right)$ point out the occurrence of one cointegration vector. The outcome involves employment of the VECM for long-run relationship analysis. All time series for Estonia are in logarithms.

Table 1

\section{Assessment of permanent terms of trade changes effect of agri-food goods for Estonia (VECM model)}

\begin{tabular}{|l|c|c|c|c|c|c|}
\hline & \multicolumn{1}{|c|}{$\begin{array}{c}\text { Equation for terms of trade } \\
\text { permanent component }\end{array}$} & \multicolumn{2}{c|}{$\begin{array}{c}\text { Equation for exports / } \\
\text { imports ratio }\end{array}$} & \multicolumn{2}{c|}{ Equation for GVA } \\
\hline Model term & Coefficient & $p-$ value & Coefficient & $p-$ value & Coefficient & $p-$ value \\
\hline const & -0.164 & 0.0015 & -4.738 & 0.0005 & -11.000 & 0.5533 \\
\hline time & -0.001 & $<0.0001$ & 4.004 & 0.0018 & 0.014 & 0.7104 \\
\hline EC1 & 0.051 & 0.0009 & 4.748 & 0.0005 & 3.201 & 0.5505 \\
\hline
\end{tabular}

Source: author's calculations based on EUROSTAT data

The VECM model incorporates following terms: constant (const), time variable (time), and errorcorrection term (EC1). Estimates of parameters for respective equations of VECM system (tab. 1) that relate the permanent change of terms of trade (hpt_ToT) to the Estonian agri-food goods exports / imports ratio (Rat) and GVA (gross value added) of agricultural industry provide evidence in support of considered variables' statistical significance in equation for terms of trade permanent component and in equation for exports / imports ratio. On the other hand, such conclusion is not to be drown in equation of GVA. 
The model estimation was followed by impulse response function (IRF) evaluation. This enabled to assess the model response to system variables' changes. The analysis led to the conclusion that an positive impulse in permanent component of terms of trade causes sharp increase in hpt_ToT and GVA variables in consecutive VECM equations. In relation to Rat variable, a rise in hpt_ToT causes Rat decrease. The stabilisation of the system is attained after two periods. Any positive impulse derived from trade balance (Rat - exports / imports ratio) has an decreasing effect on every system variable. Any increase in GVA stimulates positively remaining VECM system variables (however, the effect is weak).

The final stage of the country's study was the forecast error variance decomposition (FEVD). The outcome of FEVD after ten steps (tab. 2) makes it possible to quantify which shocks are most important to determine consecutive variables. As shown in table 2 , in the last period of the prognosis permanent changes in terms of trade (hpt_ToT) accounted for $78.18 \%$ (equation hpt_ToT) of this variable and for $18.16 \%$ of trade balance (Rat equation). Thus, the trade balance (Rat) variability could be explained in the most degree by previous changes in the trade balance. Additionally, the trade balance significantly influences GVA (GVA equation). As the analysis's consequence, one can state that terms of trade is the most exogenous factor within the considered system. On the other hand the most endogenous variable is GVA. So, trade balance is more exogenous than GVA and less exogenous than permanent terms of trade component.

Table 2

The forecast error variance decomposition (last period of prognosis) in the model (VECM) for permanent changes in terms of trade of Estonia

\begin{tabular}{|c|c|c|c|c|c|c|c|c|c|}
\hline \multirow[b]{2}{*}{ Period } & \multicolumn{3}{|c|}{$\begin{array}{c}\text { Equation for terms of trade } \\
\text { (hpt_ToT) }\end{array}$} & \multicolumn{3}{|c|}{$\begin{array}{l}\text { Equation for exports / } \\
\text { imports ratio (Rat) }\end{array}$} & \multicolumn{3}{|c|}{ Equation for GVA (GVA) } \\
\hline & hpt_ToT & Rat & GVA & hpt_ToT & Rat & GVA & hpt_ToT & Rat & GVA \\
\hline 10 & $78.18 \%$ & $20.78 \%$ & $1.02 \%$ & $18.16 \%$ & $64.09 \%$ & $17.75 \%$ & $7.90 \%$ & $43.29 \%$ & $48.81 \%$ \\
\hline
\end{tabular}
Source: author's calculations based on EUROSTAT data

Cointegration test performed for temporary terms of trade changes revealed No cointegration vector. This suggested application of VAR model for short-run study. However, the VAR model was not effective in any temporary terms of trade changes impact identification on variables under consideration.

\section{Terms of trade changes impact on agricultural industry of Lithuania}

For permanent terms of trade changes Johansen cointegration test based on trace statistical test $(r>=$ $\left.1 \lambda_{\text {trace }}=12.530 p=0.2764\right)$ and the maximum eigenvalue test $\left(r=1 \lambda_{\max }=11.026 p=0.3153\right)$ suggest the presence of a single cointegration vector. This implicates application of the VECM for long-run relationship analysis.

Assessment of permanent terms of trade changes effect of agri-food goods for Lithuania (VECM model)

\begin{tabular}{|l|c|c|c|c|c|c|}
\hline & \multicolumn{1}{|c|}{$\begin{array}{c}\text { Equation for terms of trade } \\
\text { permanent component }\end{array}$} & \multicolumn{2}{c|}{$\begin{array}{c}\text { Equation for exports / } \\
\text { imports ratio }\end{array}$} & \multicolumn{2}{c|}{ Equation for GVA } \\
\hline Model term & Coefficient & $p-$ value & Coefficient & $p-$ value & Coefficient & $p-$ value \\
\hline const & -2.902 & 0.0018 & 275.893 & 0.0301 & 1.482 & 0.1642 \\
\hline time & -0.037 & $<0.0001$ & -1.437 & 0.0193 & 0.983 & 0.3450 \\
\hline EC1 & -0.023 & 0.0017 & -2.193 & 0.0333 & 1.510 & 0.1569 \\
\hline
\end{tabular}

Source: author's calculations based on EUROSTAT data 
Analogous to Estonia study, the VECM model performed for Lithuania (tab. 3) and evaluating permanent terms of trade impact supported the claim related statistical significance of lag values of system variables (hpt_ToT, Rat, GVA) in explanation of terms of trade and exports / imports ratio. No model term was significant in GVA equation.

The impulse response function estimated for the above VECM model revealed that changes of VECM system variables trigger immediate response of the variables in the model. The model stabilises after two periods after shock. An positive impulse in permanent terms of trade positively affects terms of trade (hpt_ToT) and GVA of agriculture in Lithuania and negatively influences agri-food trade balance (Rat exports / imports ratio).

Table 4

The forecast error variance decomposition (last period of prognosis) in the model (VECM) for permanent changes in terms of trade of Lithuania

\begin{tabular}{|c|c|c|c|c|c|c|c|c|c|}
\hline & \multicolumn{2}{|c|}{$\begin{array}{c}\text { Equation for terms of trade } \\
\text { (hpt_ToT) }\end{array}$} & \multicolumn{2}{c|}{$\begin{array}{c}\text { Equation for exports / } \\
\text { imports ratio (Rat) }\end{array}$} & \multicolumn{2}{c|}{ Equation for GVA (GVA) } \\
\hline Period & hpt_ToT & Rat & GVA & hpt_ToT & Rat & GVA & hpt_ToT & Rat & GVA \\
\hline $\mathbf{1 0}$ & $78.28 \%$ & $4.86 \%$ & $16.86 \%$ & $2.48 \%$ & $67.33 \%$ & $30.19 \%$ & $10.06 \%$ & $59.39 \%$ & $39.55 \%$ \\
\hline
\end{tabular}
Source: author's calculations based on EUROSTAT data

Accordingly to the information presented in table 4, in the final year of the prognosis permanent changes in terms of trade (hpt_ToT) accounted for $78.28 \%$ (hpt_ToT equation) of this variable variability and for $2.48 \%$ of trade balance variation (Rat equation). Trade balance (equation Rat) explains $67.33 \%$ it's own variability. In the equation for GVA trade balance significantly impacts on variable GVA $(59.39 \%$ of the variance of GVA could be attributed to Rat). So, the forecast error variance decomposition study performed for Lithuania revealed that permanent terms of trade component and trade balance in Lithuanian argi-food industry generally are independent factors. Permanent terms of trade is slightly more exogenous than that variable in model for Estonia. Additionally, trade balance (Rat) relatively significantly affects GVA of agricultural industry in Lithuania.

Table 5

\section{Assessment of temporary terms of trade changes effect of agri-food goods for Lithuania (VAR model)}

\begin{tabular}{|l|c|c|c|c|c|c|}
\hline & \multicolumn{2}{|c|}{$\begin{array}{c}\text { Equation for terms of trade } \\
\text { temporary component }\end{array}$} & \multicolumn{2}{c|}{ Equation for trade balance } & \multicolumn{2}{c|}{ Equation for GVA } \\
\hline Model term & Coefficient & $\mathrm{p}-$ value & Coefficient & $\mathrm{p}-$ value & Coefficient & $\mathrm{p}-$ value \\
\hline const & 3.819 & 0.1318 & -116.676 & 0.2981 & 496.986 & 0.0004 \\
\hline hp_ToT_1 & -0.011 & 0.9637 & -11.883 & 0.5327 & 24.751 & 0.1300 \\
\hline Bal_1 & 0.006 & 0.0794 & 0.592 & 0.0191 & 0.626 & 0.0041 \\
\hline GVA_1 & -0.008 & 0.0852 & 0.496 & 0.0890 & 0.027 & 0.9093 \\
\hline
\end{tabular}

Source: author's calculations based on EUROSTAT data

Cointegration tests performed for temporary terms of trade changes revealed No cointegration vector (trace statistical test: $r>=2 \lambda_{\text {trace }}=9.228 p=0.0024$; the maximum eigenvalue test: $r=2 \lambda_{\max }=9.228$ $p=0.0024)$. This suggested application of VAR model for short-run study purposes. The model was built based on following variables: temporary terms of trade (hp_ToT), agri-food trade balance (Bal), and gross value added of agriculture (GVA). The main results of that analysis (tab. 5) may be summarized as identification of an positive impact of trade balance on all model variables. However, this variable is marginally statistically significant in the equation for temporary terms of trade changes. The remaining system variables are not statistically significant. 


\section{Terms of trade changes impact on agricultural industry of Latvia}

For permanent terms of trade changes of Latvian agriculture Johansen cointegration test based on trace statistical test $\left(r>=1 \lambda_{\text {trace }}=12.232 p=0.2975\right)$ and the maximum eigenvalue test $\left(r=1 \lambda_{\max }=12.158\right.$ $p=0.2332$ ) implicates the presence of a single cointegration vector. This results suggest application of the VECM for the relationship investigation.

Table 6

Assessment of permanent terms of trade changes effect of agri-food goods for Latvia (VECM model)

\begin{tabular}{|l|c|c|c|c|c|c|}
\hline & \multicolumn{1}{|c|}{$\begin{array}{c}\text { Equation for terms of trade } \\
\text { permanent component }\end{array}$} & \multicolumn{2}{|c|}{$\begin{array}{c}\text { Equation for exports / } \\
\text { imports ratio }\end{array}$} & \multicolumn{2}{c|}{ Equation for GVA } \\
\hline Model term & Coefficient & $p-$ value & Coefficient & $p-$ value & Coefficient & $p-$ value \\
\hline const & -8.280 & 0.0010 & -346.435 & 0.0082 & 300.171 & 0.7943 \\
\hline time & -0.107 & $<0.0001$ & 2.144 & 0.0302 & -0.742 & 0.9354 \\
\hline EC1 & 0.110 & 0.0002 & 3.916 & 0.0072 & -3.335 & 0.7934 \\
\hline
\end{tabular}

Source: author's calculations based on EUROSTAT data

Results of error-correction model (based on variables: hpt_ToT, Rat, GVA) for Latvia which are presented in the table 6, relates considered variables to permanent terms of trade changes and exports / imports ratio. System variables are not statistically valid in the equation for GVA of agricultural industry.

The impulse response function assessed for Latvia showed that positive impulse in permanent terms of trade (hpt_ToT) causes sharp rise in that variable and a similar effect in agri-food trade balance (Rat). An opposite effect was noted in GVA of agriculture. An impulse in trade balance positively stimulate trade balance and permanent terms of trade.

The forecast error variance decomposition (last period of prognosis) in the model (VECM) for permanent changes in terms of trade of Latvia

\begin{tabular}{|c|c|c|c|c|c|c|c|c|c|}
\hline & \multicolumn{2}{|c|}{$\begin{array}{c}\text { Equation for terms of trade } \\
\text { (hpt_ToT) }\end{array}$} & \multicolumn{2}{c|}{$\begin{array}{c}\text { Equation for exports / } \\
\text { imports ratio (Rat) }\end{array}$} & \multicolumn{3}{c|}{ Equation for GVA (GVA) } \\
\hline Period & hpt_ToT & Rat & GVA & hpt_ToT & Rat & GVA & hpt_ToT & Rat & GVA \\
\hline $\mathbf{1 0}$ & $73.92 \%$ & $14.96 \%$ & $11.12 \%$ & $10.93 \%$ & $33.22 \%$ & $55.84 \%$ & $8.20 \%$ & $29.43 \%$ & $62.37 \%$ \\
\hline
\end{tabular}

Source: author's calculations based on EUROSTAT data

Results of the FEVD analysis shown in table 7 indicate that in the last period of the prognosis permanent changes in terms of trade (hpt_ToT) accounted for $73.92 \%$ of its own variability (hpt_ToT equation) and for $10.93 \%$ variability of trade balance (Rat equation). Hence, trade balance of agri-food goods is influenced more extensively by GVA (55.84 \% of explained variability in equation Rat) than through permanent component of terms of trade. Furthermore, the trade balance relates significantly to GVA ( $29.43 \%$ of explained variability of GVA in GVA equation).

Information presented in table 7 suggest that the impact of permanent terms of trade changes on the trade balance of agri-food goods variability in Latvia is less meaningful than the opposite influence. The FEVD analysis revalidated remarks related to previous models. However, the scope of trade balance exogeneity in Latvian model is lower than in model for Lithuania. This leads to the conclusion that trade balance shocks are not so crucial to determine remaining (considered in the VECM model) variables in Latvian economy. Permanent terms of trade component of Latvian agriculture seems to be to some extent more independent factor than remaining model elements. 
For short-run terms of trade changes analysis Johansen cointegration test implied application of VAR model. However, model evaluating the impact in temporary indicator's changes lead to rejection of the statement combining terms of trade shock with trade balance.

\section{Conclusions, proposals, recommendations}

The main results of the research may be summarized as follows.

1) The terms of trade time series contain temporary and permanent components. In order to split the series development into temporary and permanent categories, the data were transformed by means of Hodrick-Prescott filter.

2) The long-run assessment of terms of trade changes is made using vector error correction model (VECM). The short-run estimates of terms of trade fluctuations are based on vector autoregression model (VAR).

3) Assessments of permanent changes in terms of trade relate this variable and trade balance changes to terms of trade development, and to trade balance (exports / imports ratio) development.

4) On the other hand, long-run impact of GVA (gross value added) of agricultural industry on the other considered variables is not meaningful.

5) The research identified an impact of temporary terms of trade socks on GVA of agricultural industry of Lithuania. The study results did not reveal any statistically significant short-run effect of the terms of trade shocks on trade balance and gross value added in Estonia and Latvia.

6) The study revealed that the trade balance of agri-food products has meaningful effect on gross value added of agricultural industry in Lithuania.

7) For short-run analysis purposes it is worth to consider shorter time frames and higher frequency data, as these may yield insights into the way the examined variables relate each other.

\section{Bibliography}

1. Agenor, P., Aizenman, J. (2000). Savings and the Terms of Trade Under Borrowing Constraints, NBER Working Paper No. 7743, Cambridge, MA, pp. 3-12.

2. Chowdhury, A. (2003). Do asymmetric terms of trade shocks affect private savings in a transition economy? Discussion Papers No. 3, Bank of Finland Institute for Economies in Transition, Helsinki, pp. 1-32.

3. Harberger, A. (1950). Currency Depreciation, Income and the Balance of Trade. Journal of Political Economy, 58, pp. 47-60.

4. Hodrick, R., Prescott, E. (1997). Postwar U.S. Business Cycles: An Empirical Investigation. Journal of Money, Credit and Banking, 29(1), pp. 1-6.

5. Johansen, S. (1988). Statistical analysis of cointegration vectors. Journal of Economic Dynamics Control, 12(2-3), pp. 231-254.

6. Kent, Ch., Cashin, P. (2003). The Response of the Current Account to Terms of Trade Shocks: Persistence Matters. IMF Working Paper, No. 143, pp. 13-14.

7. Kusidel, E. (2000). Modele wektorowo-autoregresyjne VAR. Metodologia i zastosowania (VAR - Vector Autoregressive Models. Methodology and Applications). Lodz, Absolwent, pp.14-58.

8. Kwiatkowski, D., Phillips, P., Schmidt, P., Shin, Y. (1992). Testing the Null Hypothesis of Stationarity against the Alternative of a Unit Root. Journal of Econometrics, 54, pp. 159-178.

9. Laursen, S., Metzler, L. (1950). Flexible Exchange Rates and the Theory of Employment. Review of Economics and Statistics, No. 32(4), pp. 281-299.

10. Lutkepohl, H. (1991). Introduction to Multiple Time Series Analysis, Springer-Verlag, Berlin-Heidelberg, pp. 1-479.

11. Turnovsky, S. (1997). International Macroeconomic Dynamics, MIT Press, Cambridge, pp. 83-86.

12.Wang, P. (2009). The Economics of Foreign Exchange and Global Finance. Springer, Berlin, pp. 109-118. 